\title{
The Next Step in African Development: Aid, Investment, or Another Round of Debt?
}

\author{
Michael W. Nicholson ${ }^{1} \&$ Sarah C. Lane ${ }^{2}$ \\ ${ }^{1}$ U.S. Agency for International Development, Liberia \\ ${ }^{2}$ U.S. Agency for International Development, Washington, USA \\ Correspondence: Michael W. Nicholson, USAID/Liberia, 502 Benson Street, Mamba Point, Monrovia, Liberia. \\ E-mail: mnicholson@usaid.gov
}

Received: March 26, $2013 \quad$ Accepted: April 10, $2013 \quad$ Online Published: May 21, 2013

doi:10.5539/ijef.v5n6p104 URL: http://dx.doi.org/10.5539/ijef.v5n6p104

The views expressed in here are those of the authors and do not necessarily reflect those of the U.S. Agency for International Development.

\begin{abstract}
Amidst intense debt relief, and alongside dramatically improved governance, investment and growth increased substantially across Africa during the past decade. This paper interprets the timing of the Heavily Indebted Poor Countries (HIPC) Initiative, launched by the IMF and World Bank in the late 1990s, as a natural experiment to see whether these positive trends were specific to Africa, or specific to HIPC countries, as well as whether debt relief itself manifests deeper structural shifts in economic governance. As many HIPC countries are presently raising their external public debt levels, we question whether these loans would be a "good kind of debt" that leads to investment and development or the beginning of a new debt cycle potentially leading to another round of debt relief programs. Data on external debt and capital development for 46 countries of sub-Saharan Africa and six other HIPC countries outside of Africa is used to evaluate structural breaks and parameter stability in a longitudinal panel analysis. Incorporating an identification strategy that isolates the debt relief initiatives from endogenous improvements to economic governance, we find that they had a statistically significant impact on foreign investment flows to Africa. The data suggests that even alongside new escalating debt levels, investment will likely be the next step in African development.
\end{abstract}

Keywords: debt relief, foreign direct investment, panel-data econometrics, foreign aid

\section{Introduction}

The cycle of external debt for African governments has burdened their countries since the wave of independence in the 1950s and 1960s. Continuing efforts at debt relief through the $20^{\text {th }}$ century proved ineffectual, as governments, tending to optimize on a short time horizon, would continue to borrow into indebtedness (Note 1). Times, however, may be changing, as success stories about investment opportunities on the African continent abound (Note 2).

This paper investigates the apparent transition from impoverishing debt to market-based investment in Africa, specifically focusing on the Heavily Indebted Poor Countries (HIPC) Initiative launched by the International Monetary Fund (IMF) and World Bank in the late 1990s. Our results suggest that a structural break in the nature of African debt and investment occurred in the last decade. Debt relief may have eliminated a disequilibrium of instability to create incentives for profit-oriented commercial loans (Addison, 2006). These loans would be a "good kind of debt" leading to investment and development.

We incorporate an identification strategy that isolates debt relief from accompanying policy improvements of economic governance. Endogeneity arises because HIPC initiatives occurred simultaneously with adoption of the exact types of policies that improve a country's competitiveness as a destination for foreign direct investment (FDI). Moreover, these policies were often adopted precisely to reach the "decision point" of the debt relief, making it difficult to tease out whether the policies, the debt relief, or both lead to a structural shift. This interaction causes an inherent challenge for the analysis, a dilemma similar to isolating the impact of WTO accession on a country's trade levels since the accession process deliberately focuses on the policies and 
commercial environment that facilitates international trade as a run-up to WTO membership (Rose, 2003).

Our econometric analysis treats the HIPC debt relief program as an event study by creating control groups for HIPC countries and African countries. These two comparison sets of longitudinal panel data allow us to identify the specific impacts of HIPC while isolating pan-African geo-economic and political trends. The results show that following debt relief, determinants of FDI in HIPC-designated countries reflect those of other countries in the world. We also show that sub-Saharan Africa as a geo-political designation for economic activity does not matter: if Africa's recent economic history differs from the rest of the world, it appears due to the features of being poor and indebted rather than something inherent to the continent. The HIPC initiative, which included policy improvements and debt relief, altered the economic landscape of Africa, and, as a result, FDI has flowed into the continent.

The implications are that following the debt relief initiatives, we can anticipate that FDI will respond to incentives in Africa just as in other regions. If the continent is "open for business", the ability for countries to again engage in public financing to improve market conditions should be anticipated as a positive turn of events. The paper does not consider whether FDI causes growth in HIPC countries, such as by Reiter and Steensma (2010), nor whether debt relief "buys" growth, such as Hepp (2008). Our focus is the impact of debt relief initiatives on the parameters of FDI determinants in developing countries.

The next section provides background on debt relief measures from the decade of the 2000s. Section 3 discusses trends in private investment in Africa. Section 4 provides an econometric analysis of the data on debt and investment in Africa, and section 5 offers concluding remarks.

\section{Literature Review and Context}

\subsection{Africa Rising}

The results of this paper suggest that foreign aid in the form of debt relief conditional on improved economic governance has led to increased foreign investment and capital formation on the continent (Note 3 ). These effects are evident in how private markets now view the continent. For example, McKinsey (2010) identified several African "lions" that have recently experienced growth acceleration and increased economic momentum. The report highlights a group of countries in sub-Saharan Africa with specific commercial opportunities due to a combination of export-oriented economies and the diversification of gross domestic product (GDP). As Africa becomes a profitable investment destination, governments in former HIPC countries have begun to increase debt levels, ostensibly for investment to support growth opportunities. This new borrowing may not necessarily lead to a new debt cycle, if a wave of fundamental changes in economic policy and democratic governance has taken place across the continent, as we postulate.

Radelet (2010) describes 17 countries in Africa as "success stories" due to sustained economic growth over the past decade. He identifies five specific reasons why emerging African countries have been growing: (1) democracy; (2) economic policies; (3) debt relief; (4) technology; and (5) entrepreneurship. Radelet states that the combination of these five factors helped to bring these countries out of a low-growth equilibrium, and that progress has been made in a variety of social, governance and economic factors that have helped emerging African countries grow more rapidly. Many of these factors reinforced each other; for example, eliminating a debt-to-GDP ratio of nearly 3,000 percent, as Liberia did in the mid-2000s, necessitates better economic policies in general and benefits substantially from an end to conflict and welfare. Radelet cites the cause of the debt crisis in Africa as the result of "poor economic management, unaccountable and highly corrupt governments, large amounts of borrowing at government rates, and a deep global economic shock." He states that the fundamental shift for emerging Africa came from reforms in democratic and economic policies, but the growth has been sustainable as a result of debt relief, new technologies and entrepreneurship.

Clements, Bhattacharyua, and Nguyen (2005) suggest that Western aid agencies initiated the HIPC program on the basis that debt burden in the heavily indebted nations was stifling growth and creating impossible conditions for the countries to eradicate poverty. The literature on debt and economic growth holds that unsustainable debt-to-GDP stock creates disincentives for investment in the domestic economy because the government must divert revenue to service debt rather than invest in the domestic economy; rising debt levels then increase investor uncertainty. Unsustainable debt levels are thus linked with inflation-generating monetary policy and outright expropriation of private firms. Under such uncertainties investments tend to be in projects of a shorter duration and quicker returns and thus countries are less apt to invest in long term sustainable foreign direct investment. Furthermore, debt overhang has the tendency to delay necessary macro-fiscal policy reform.

Dorsey (2008) demonstrates the extent that capital flowed to debt-forgiven countries following debt relief. The aggregate current account deficit of low income countries fell from 3 percent in the mid-1990s to a near balance in 
2006. Following the debt forgiveness plans, development aid has taken the form of grants instead of lending. Dorsey (2008) also points out that the African countries that have most benefited from this inflow are those with extractive sectors such as oil and mineral wealth. FDI flows to non-extractive-based economies have increased, due in part to concurrent policies such as the liberalization of the economy and a general opening of the market to foreign investors.

As Easterly (2002) suggested, in advance of the HIPC Initiative, debt relief should be offered only to governments that have demonstrated a clear shift in their orientation towards macroeconomic policy; otherwise, the program would essentially reward poor economic governance. To be eligible for the program, countries had to meet a set of conditions, both to improve their economies and governance to be eligible for debt relief. If this has held true, debt relief may be a "proxy-plus" for fundamental changes in economic governance undertaken by the debt relief recipients.

\subsection{Debt and Debt Relief}

In August of 1982, the year that Mexico defaulted on its sovereign debt triggering a global debt crisis, the average external debt-to-export ratio for sub-Saharan Africa was 325 percent, substantially higher than the "heavily indebted" threshold of 150 percent. African debt was stifling development efforts. In the mid-1980s, the Paris Club began to address these debt issues, first by restructuring loans and then through debt forgiveness (Note 4). While the Paris Club was making some progress in debt relief, debt in Africa continued to soar. By 1992, the average external debt-to-export ratio for sub-Saharan Africa countries reached 760 percent, with many countries experiencing external debt-to-export ratios far higher. The most extreme case of indebtedness occurred in Liberia where, in 1997, the debt-to-export ratio reached an astonishing 9,212 percent. However, Liberia was not alone in Africa in having an extremely high debt burden. Since the beginning of the debt crisis in 1982 more than a dozen African countries had persistent external debt-to-export ratio of more than 1,000 percent (Note 5). See Table A-1 in the Appendix.

In 1996, the World Bank and IMF launched the HIPC initiative with the goal of "ensuring that no poor country faces a debt burden it cannot manage." (Note 6) Of the 39 countries eligible for HIPC, 33 were in Africa, as shown in Figure 1 (Note 7). The HIPC initiative was a new effort to provide debt relief to countries that were making strong efforts to address poor economic and political policies. The initiative was a two stage process consisting of a Decision Point stage and a Completion Point stage. To reach a Decision Point, countries must have established a track record of macroeconomic stability and completed a Poverty Reduction Strategy Paper (PRSP). In this phase, the country received provisional debt relief. To be eligible for the Completion Point stage, a country needed to have maintained macroeconomic stability, begun implementing reforms agreed to at the Decision Point and have implemented the PRSP for at least one year. At the Completion Point stage, countries received the full debt relief agreed to at the Decision Point. In order to receive relief, the HIPC initiative required countries to address the problems that led to debt.

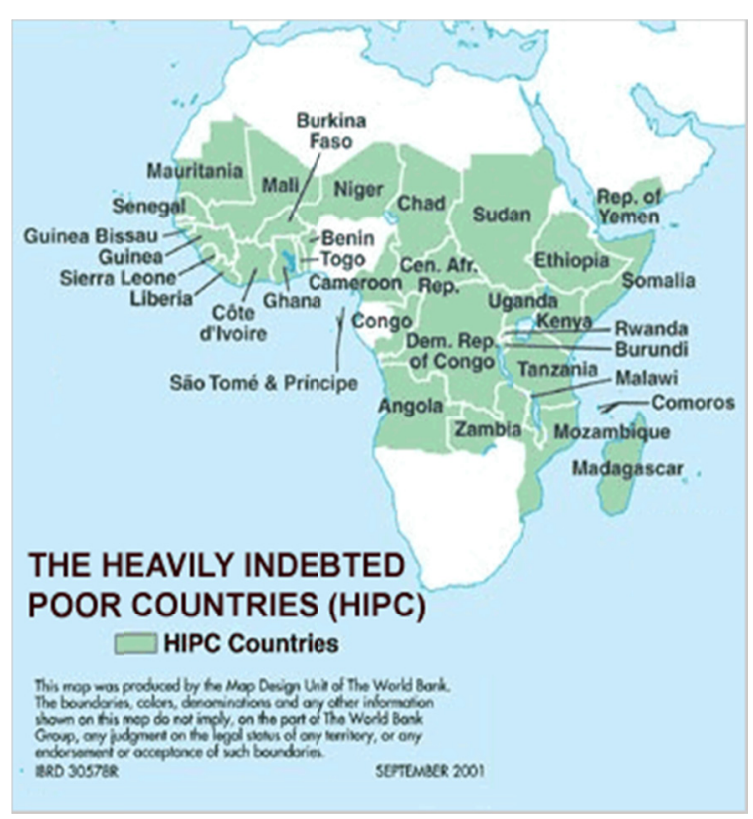

Figure 1. HIPC countries in Africa 
In 2005, the IMF and World Bank initiated the Multilateral Debt Relief Initiative (MDRI) to further increase debt relief to reach the Millennium Development goals. MDRI provides for 100 percent debt relief to eligible countries on debt from the IMF, World Bank and the African Development Bank. See Figure 2.

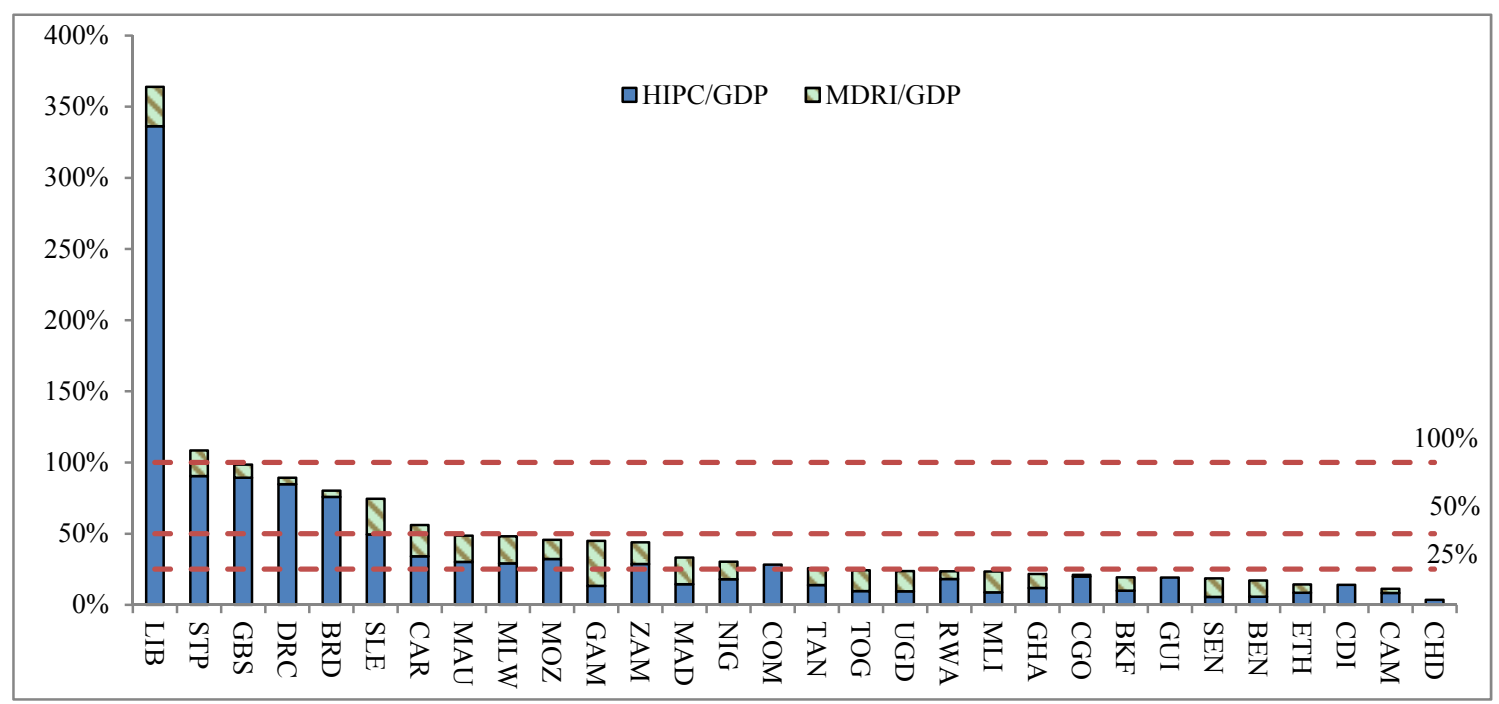

Figure 2. Total debt relief/GDP (2009), all countries

Debt relief for the West African country of Liberia is, literally, off the charts. To allow for visibility in a comparison to other recipients of debt relief in Africa, Figure 3 provides the same information as Figure 2 with Liberia excluded to adjust for the outlier.

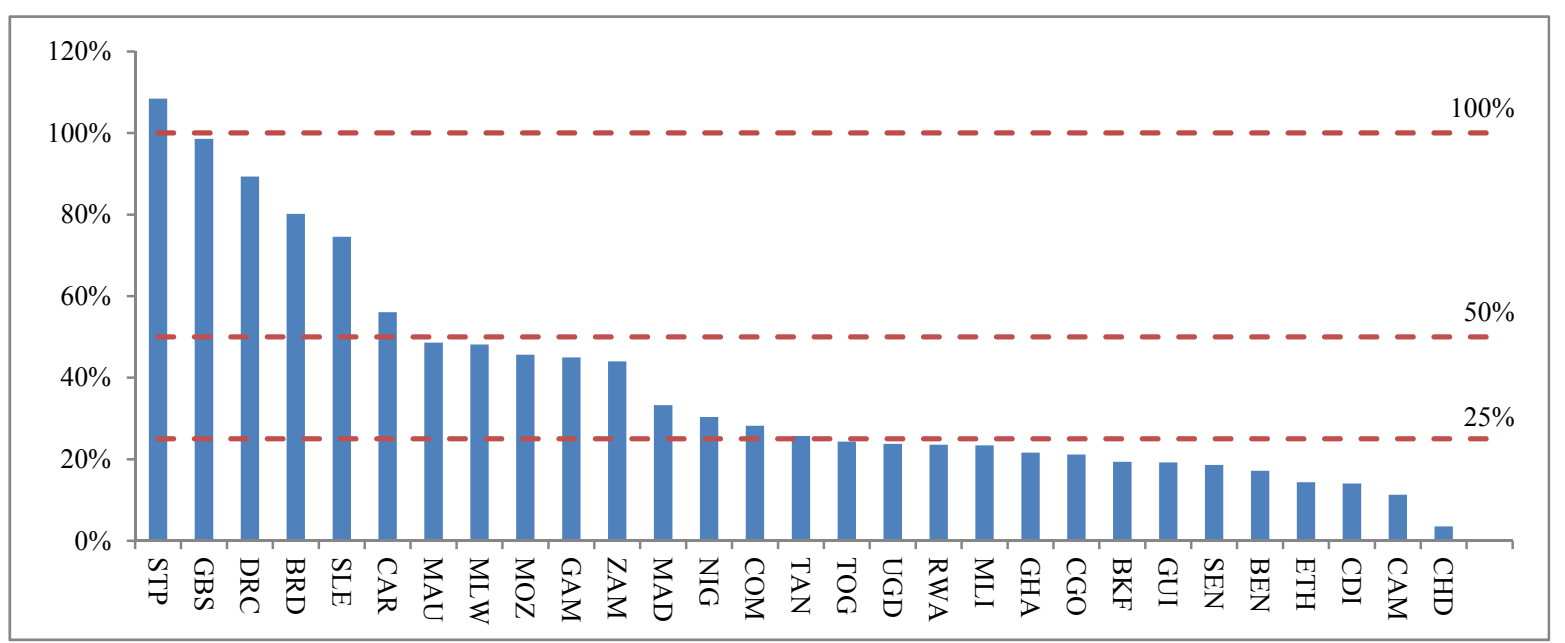

Figure 3. Total debt relief/GDP (2009), Liberia excluded

Thirty African nations received nearly $\$ 50$ billion in debt relief as part of the HIPC initiative and another \$24 billion as part of MDRI between 2000 and 2009 (Note 8). The impact of this debt relief is illustrated in Figure 4, which shows a dramatic decline in external debt as percentage of GDP from more than 75 percent in 1994 to less than 20 percent by 2000 . As could be expected, African external debt fell substantially immediately following the relief initiatives. Figure 4 shows a clear downward trend from 1995 to 2006, but since then, the amount of external debt is again increasing to more than it was in the height of the debt crisis. The debt-to-GDP ratio has been quite flat for the last five years, and in 2010, the average external debt-to-export ratio for African countries was 136 percent, below the 150 percent threshold to be considered heavily indebted. However, debt in real dollars increased from $\$ 154$ billion in 2006 to $\$ 189$ billion in 2010. Liberia, the overachiever in debt relief, has recently crafted a medium-term expenditure framework to increase its public debt to 45 percent of GDP over the next three years in part through the issue of new treasury bills (Note 9). Should this be a concern to the donors who recently paid off $\$ 75$ billion of debt? 


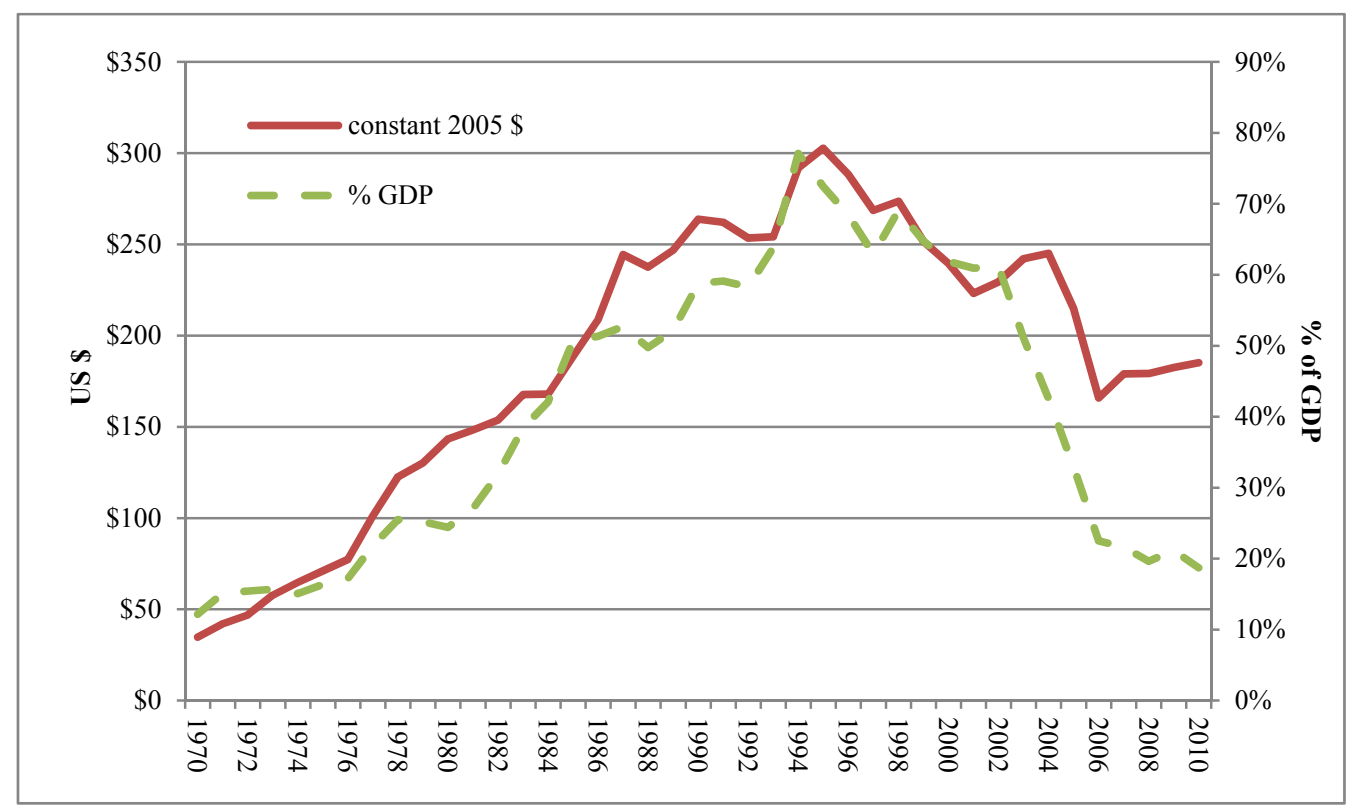

Figure 4. African external debt (2005 US\$ and as a percent of GDP)

According to Reisen and Ndoye (2008) the optimal debt-to-export ratio is no more than 150 percent. However, the average debt-to-export ratio for African countries in the 1980s and 1990s reached a peak of more than 700 percent. Only recently, has the average debt-to-export ratio fallen below the 150 percent level as recommended by Reisen and Ndoye.

As described earlier, each recipient country under debt relief faced two key dates: a "Decision Point", under which they were deemed to be eligible for debt relief; and a "Completion Point", when they essentially graduated from the debt relief program. Figures A1 to A4 in the appendix provide information about certain debt flows with highlights of these points for each country. At times, they illustrate the dramatic increase in FDI for particular countries. This relationship appears particularly strong in countries that have experienced consistent, robust growth in recent years. In the early 2000s, African countries began to take on new and better economic and democratic policies and they had a lessening debt burden. Around this time many African countries emerged from the low growth equilibrium many of them had been stuck in for decades. In this context, we consider the HIPC decision point as the start of a structural break; a kind of "proxy plus", where both debt relief and policy changes made it possible for many African countries to break the debt circle and begin to grow their economies and reduce poverty. Further evidence of this structural break is shown in the World Bank poverty numbers where, in 2008, the absolute number of people living in poverty in Africa fell for the first time in history (Note 10).

\section{Trends in African FDI}

Debt relief represents one form of official development assistance (ODA) intended to spur long-term market-based economic growth. Moss (2011) refers to the concepts of "digging holes" and "capital flows", of which the former represents service provision and infrastructure development, while the latter represents assistance intended to spur an enabling environment for growth. Trends in African FDI indicate whether ODA in the form of debt relief has appropriately triggered capital flows into a relatively assistance-dependent region.

Throughout the latter half of the twentieth century, Africa lagged the rest of the world with regard to the creation or receipt of private investment, capital formation, and global FDI flows. For its primary source of external capital, Africa relied on development aid, usually in the form of concessionary loans. In an empirical analysis, Nicholson (2012) identifies sub-Saharan Africa as an "AID-oriented region" in which aid flows continue to dominate private investment flows (Note 11). As Figure 5 shows, the African share of FDI in developing countries was more than 50 percent in the 1970 's, reaching a peak of 59 percent in 1972, but slipped below 10 percent by the 1990s; meanwhile, Africa's share of development aid has reached around 40 percent (Note 12). 


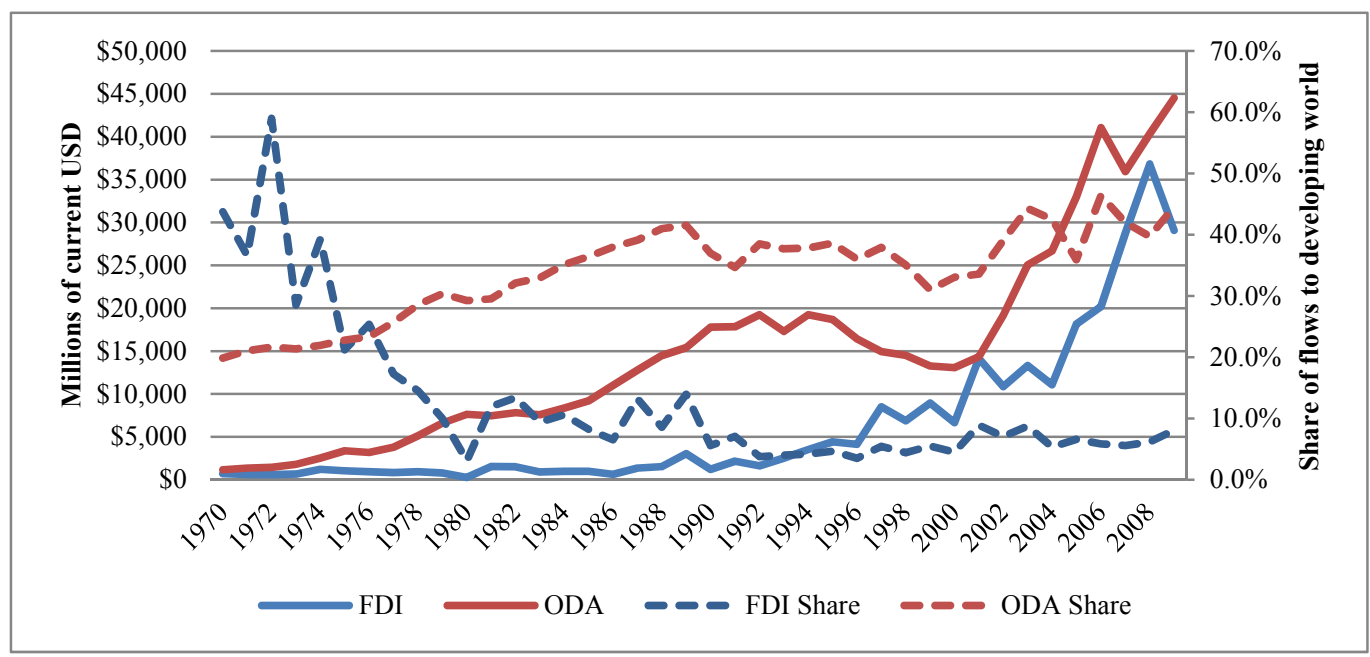

Figure 5. Trends in development aid and FDI in Africa

Asiedu (2002) investigates the "Africa effect" in which the explanatory factors for FDI in developing countries may not have similar force in sub-Saharan Africa. Using data for the years 1988 to 1997, she finds that determinants of FDI such as return on investment and infrastructure have positive impacts in developing countries outside of Africa but have no statistically valid impact in sub-Saharan African countries (Note 13). In addition, she finds that "openness to trade", as defined by the ratio of total trade to GDP, promotes FDI in all developing countries but has a significantly smaller marginal impact in sub-Saharan Africa. She concludes that, on this metric, Africa is different and suggests that effective policies elsewhere may not be effective here. Asiedu explains the lack of explanatory power of return on investment as due to a reputation effect across the continent, including risk of investment, lack of information, and the risk of policy reversal. The openness-to-trade indicator may be less effective in Africa due to the debt cycle story, and infrastructure could be related to resource-based FDI in Africa. Collier (2007) suggests that a potential issue for investment in Africa may have been the "time-consistency" problem, in that present governments are unable to bind themselves from confiscating investments in the future which then diminishes investment. This dynamic, however, may have changed based on a structural policy reform of the 2000 s.

Anyanwu (2012) finds in an analysis of FDI from 1996 to 1998 that FDI flows to African countries are positively associated with market size, openness, rule of law, clusters, and natural resources. He also found that FDI is negatively correlated with higher financial development in Africa, and that "higher FDI goes where foreign aid goes." He argues that foreign aid affects FDI through a "positive vanguard effect", by lowering perceptions of investment risks and cultivating donor-specific norms, while also improving social and physical infrastructure.

In sub-Saharan Africa, incoming FDI increased from US\$6.7 billion in 2000 to US\$25.7 billion in 2010. With these trends, foreign investment has become a much more significant source of capital for investment in African countries and in 2009 accounted for 18 percent of their gross fixed capital formation (Note 14). The catalyst for the change in investment flows could be a number of factors, including debt relief or other types of development aid. We reassess these statistics under the hypothesis that the debt relief programs represent a potential structural break in the African investment climate. The programs themselves may be representative of a broader geo-political shift in Africa: a post-war and post-debt climate of development.

\section{Identification Strategy and Econometric Analysis}

Our identification strategy is based on the natural experiment presented by the HIPC debt relief program of the 2000s, by creating control groups of "non-HIPC countries in Africa" and "HIPC countries outside of Africa." These two comparison sets of longitudinal panel data allow us to identify the specific impacts of HIPC while isolating pan-African geo-economic and - political trends. The identifying assumption is simply that HIPC debt relief initiatives affected only those countries that received debt relief, with all other differences among countries captured by either geography, fixed effects, or other relevant controls. By including both non-HIPC countries in Africa and HIPC countries outside of Africa we obtain sufficient heterogeneity to capture the impact of the policies.

To this point, we engaged in three different tests, outlined in Table 1. 
Table 1. Different tests

\begin{tabular}{|c|c|c|}
\hline $\begin{array}{l}\text { Did something happen in } \\
\text { Africa? }\end{array}$ & $\begin{array}{l}\text { Clemente, Montañes, and } \\
\text { Reyes (1998) }\end{array}$ & $\begin{array}{l}\text { - Solves for global max in t-stat to identify "optimal" structural break over } \\
\text { time }\end{array}$ \\
\hline $\begin{array}{l}\text { Did it affect the } \\
\text { determinants of FDI? }\end{array}$ & Elliot and Müller (2006) & - Analysis of parameter stability of coefficients \\
\hline $\begin{array}{l}\text { Was it a result of debt } \\
\text { relief? }\end{array}$ & $\begin{array}{l}\text { Natural Experiment around } \\
\text { an Event Study }\end{array}$ & $\begin{array}{l}\text { - Control vs. HIPC shows whether the effects were due to HIPC or not } \\
\text { - Control vs. Africa shows whether the effects were African-centric or not } \\
\text { - Control vs. "Event" shows whether the effects were due to debt relief, or to } \\
\text { a "proxy plus" }\end{array}$ \\
\hline
\end{tabular}

We collected data on debt, gross capital formation, and FDI from the World Development Indicators on 42 sub-Saharan African countries from 1970 to 2010 to test this proposition (Note 15). Table 2 describes the data used in the analysis with summary statistics presented in the appendix using determinants suggested by Anyanwu (2012).

Table 2. Data description

\begin{tabular}{ll}
\hline Variable & Definition \\
\hline FDIflows & Foreign direct investment, net inflows \\
UrbPop & Urban Population ( percent of total) \\
GDPpc & GDP per capita (constant $2000 \$$ ) \\
Trade & Trade ( percent of GDP) \\
Credit & Domestic credit to private sector ( percent of GDP) \\
ExRate & Official exchange rate (local currency per US\$, period average) \\
Telephone & Telephone lines (per 1,000 people) \\
ODAflows & Net ODA received \\
GDPgrowth & GDP growth (annual percent) \\
\hline
\end{tabular}

Source: WDI Tables.

\subsection{Evidence of a Shift: Structural Breaks in Debt and FDI}

As shown in Figure 4 above, debt in constant dollars tracks very closely with debt as a percentage of GDP until around 2004 or 2005. In recent years, debt in constant dollars has slightly risen while debt as a percentage of GDP has fallen. Although African debt levels in nominal terms are beginning to return to pre-relief totals, could this recent increase represent investment that leads to growth? If there has been a fundamental change in the nature of public and private loans in Africa, it could manifest itself in macroeconomic data through a shift in the estimated relationships between different variables. For example, if debt prior to the break funded activities less conducive to economic growth, such as personal consumption or warfare, the estimated relationship between debt and growth would be different. In statistical terms, there would be a difference in the estimated coefficients at some measurable significance: that is, a structural break.

Clemente, Montañes, and Reyes (1998) develop tests that allow for the data to reveal structural breaks in a time series, which involves a global search for the maximum absolute value of the test statistic; as Baum (2005) describes the process, it yields "the strongest rejection of the unit root null hypothesis." We employ this test to identify specific shifts in the data to provide an indication of whether a statistically significant shift occurred for individual countries of Africa over the past decade; that is, whether something fundamentally changed in the relationship of debt and investment.

Figure 6 shows the results for the FDI series for the example country of Liberia. The clemao test identifies the optimal structural break for Liberia in 2009, the year between its decision point and completion point. Note also the sharp movement in the FDI time series in 1989, the year that hostilities erupted in the country. The Stata command clemao2, incorporating the double-break model of Baum, Barkoulas, and Caglayan (1999) accounts for the possibility of two breaks and respects the implications of a both a global and a local maximum. 
Clemente-Montañés-Reyes single AO test for unit root in series: fdi

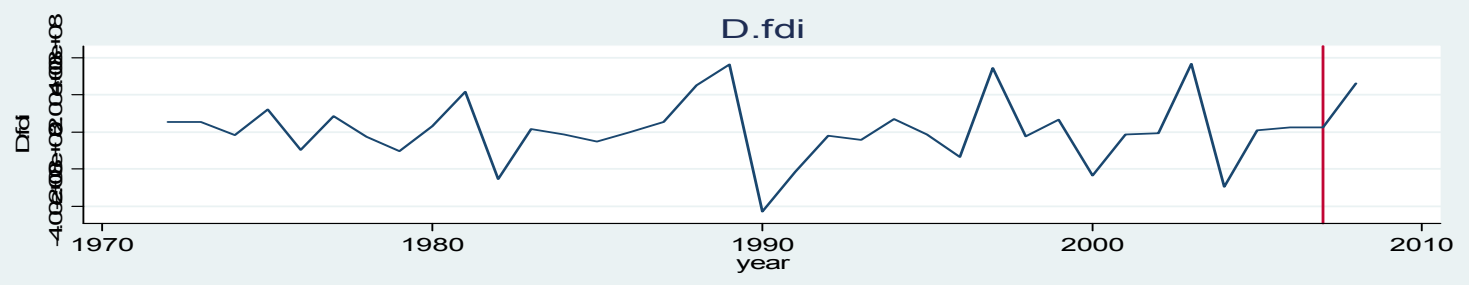

Breakpoint t-statistic: min at 2007

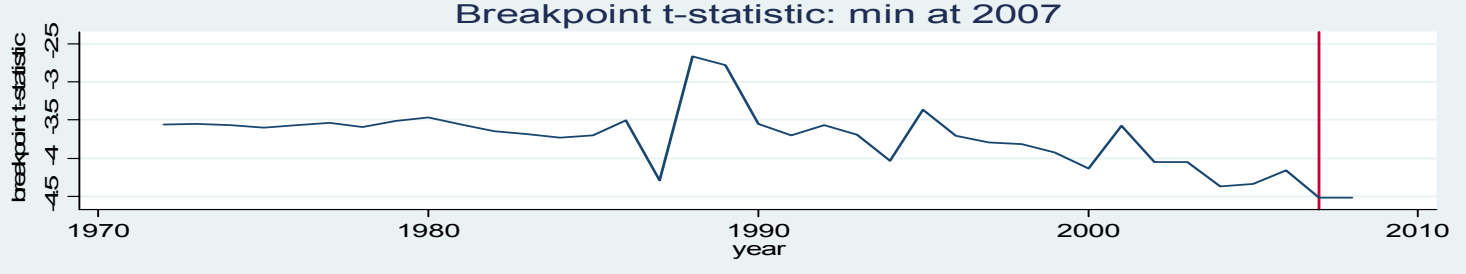

Figure 6. Clemao analysis of structural break

Tables A-3 and A-4 in the Appendix show, the structural breaks for debt and FDI, respectively, for all African countries. For exposition, Figure 7 shows histograms of the data in those tables. These histograms show debt with a peak in the late 1980s and FDI with a peak in the mid-2000s. This visual evidence is consistent with a story that a debt crisis occurred in Africa in the mid-1980s that was resolved by the mid-to-late 2000s, after which time foreign investment began to flow to the economies of the continent.

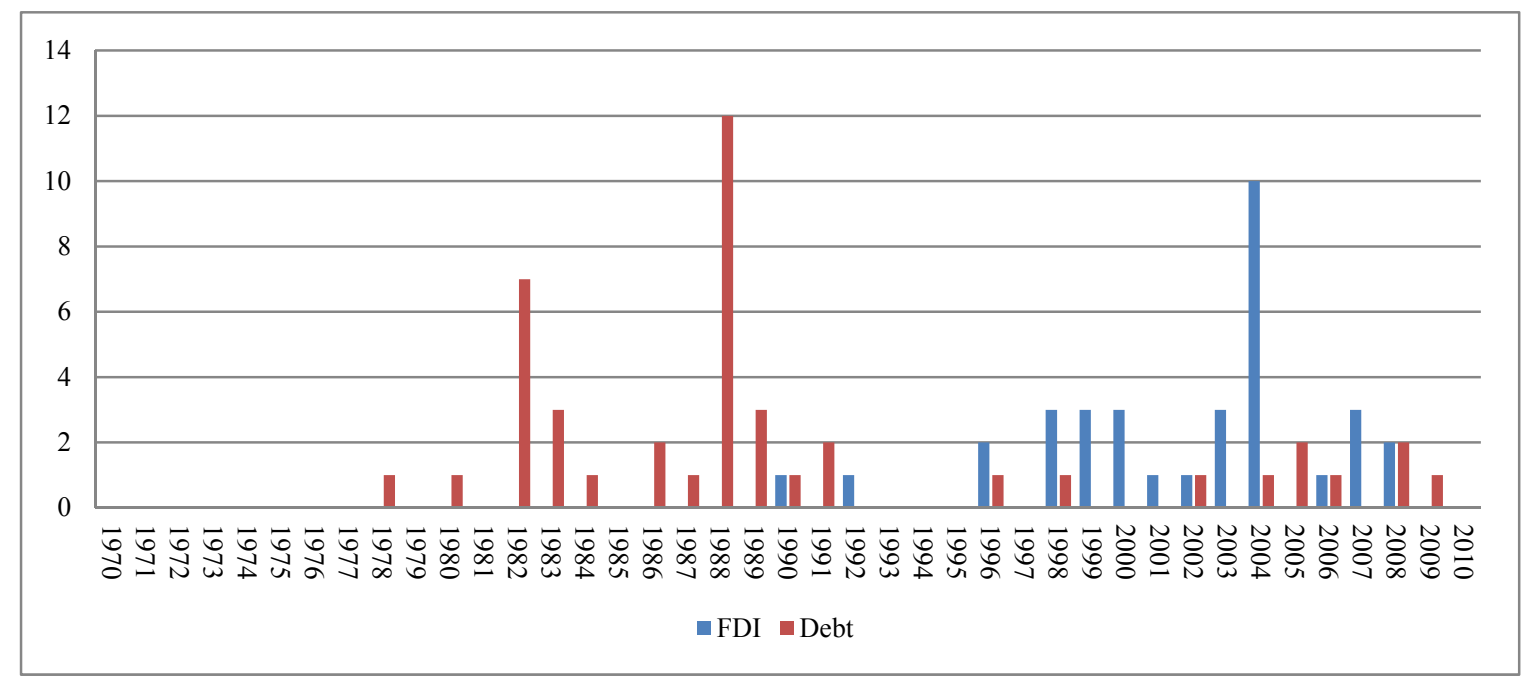

Figure 7. Structural breaks for FDI and debt

Table 3 shows the statistical relationship between external debt and private investment, as measured by gross capital formation and FDI. A negative relationship appears to exist between debt stock and gross capital formation, but this effect disappears when accounting for country-specific features through the inclusion of fixed effects. The flow of FDI as a share of GDP, however, is shown to be negatively related to external debt stocks when accounting for country and year fixed effects. These results suggest that lowering debt could increase FDI in a country. 
Table 3. Debt/GDP impact on private investment

\begin{tabular}{lll}
\hline & Gross Capital Formation $(\mathrm{n}=1,473)$ & Foreign Direct Investment $(\mathrm{n}=1,495)$ \\
\hline External Debt & $\mathbf{- 0 . 0 0 7 1 ^ { * * }}$ & $\mathbf{0 . 0 0 5 8 * * *}$ \\
(no Fixed Effects) & $(-2.11)$ & $(3.69)$ \\
$\mathrm{R}^{2}$ & 0.0030 & 0.0090 \\
\hline External Debt & $\mathbf{0 . 0 0 4 0}$ & $\mathbf{- 0 . 0 1 2 1 * * *}$ \\
(with Fixed Effects) & $(0.77)$ & $(-6.18)$ \\
$\mathrm{R}^{2}$ & 0.0361 & 0.1045 \\
\hline
\end{tabular}

Notes: T-statistics in parentheses. $* * * 99$ percent significant $* * 95$ percent significant $* 90$ percent significant.

\subsection{Impact on FDI: Changes in Parameter Stability}

Debt management, however, is not so much a determinant of FDI as it is a proxy for general conditions of economic governance and so we check if a structural break has occurred among the determinants of FDI in the same timeframe as debt relief. Although these results do not imply causality, they demonstrate that the changing nature of FDI flows to Africa are strongly linked temporally with the debt relief initiatives.

While the determinants of FDI flows have been discussed extensively in the economic literature (Note 16), research on Africa has tended to emphasize its differences. As referenced above, Asiedu (2002) concludes that the determinants of FDI may differ in Africa compared to elsewhere. As her data ended with 1997, the period prior to events investigated in this paper, Table 4 replicates the analysis using data from 1970 to 2010. As found by Asiedu, little correlation exists between openness and return on investment on FDI in Africa. Moreover, a Chow Test for the break year 2004 suggests that with regards to the determinants of FDI, no structural break exists for these determinants.

Table 4. Replicating Asiedu (2002)

\begin{tabular}{|c|c|c|}
\hline & $\begin{array}{l}\text { FDI } \\
(\mathbf{n}=37)\end{array}$ & \\
\hline \multirow[t]{2}{*}{ Openness } & 0.048 & -0.020 \\
\hline & (1.33) & $(-0.50)$ \\
\hline \multirow[t]{2}{*}{ Telephones } & $612.3 * * *$ & $975.3 * * *$ \\
\hline & (4.17) & $(5.20)$ \\
\hline \multirow[t]{2}{*}{ ROI } & -138.981 & -693.870 \\
\hline & $(-0.29)$ & $(-1.63)$ \\
\hline \multirow[t]{2}{*}{ growth } & & -2.068 \\
\hline & & $(-0.32)$ \\
\hline \multirow[t]{2}{*}{ Govt } & & $-0.418 * * *$ \\
\hline & & $(-3.76)$ \\
\hline \multirow[t]{2}{*}{ Money } & & -0.000 \\
\hline & & $(-0.09)$ \\
\hline Intercept & -515.917 & -957.189 \\
\hline R_sq & 0.7218 & 0.8040 \\
\hline Chow test (2004): & $F(3,30)=0.03$ & Prob $>F=0.9920$ \\
\hline
\end{tabular}

For individual countries, however, the relationship between FDI and African economies appears to have changed. Anyanwu (2012) asks: "Why Does Foreign Direct Investment Go Where It Goes?" and provides updates on the statistically relevant determinants of FDI for sub-Saharan countries. We use these previous analyses of FDI in Africa to investigate the impact of debt relief initiatives on foreign capital flow to the region. Replicating the Anyanwu determinants, we incorporate the Stata test $q L L$ (quasi-local likelihood), based on Elliot and Müller (2006), to test for parameter instability. It tests whether any structural break occurred over the time period in question. Table 5 shows the $q L L$ determinants for all countries, clearly suggesting a shift in the determinants of FDI for many African countries between 1970 and 2010. 
Table 5. Parameter stability for determinants of FDI, individual African countries

\begin{tabular}{llllll}
\hline Country & t-stat & Country & t-stat & Country & t-stat \\
\hline Angola & no data & Gambia, The & -33.445 & Rwanda & -36.48 \\
Benin & -33.135 & Ghana & -95.697 & Sao Tome and Principe & no data \\
Botswana & -190.536 & Guinea & -669.997 & Senegal & -28.831 \\
Burkina Faso & -42.947 & Guinea-Bissau & -316.18 & Seychelles & -38.58 \\
Burundi & -124.561 & Kenya & -42.199 & Sierra Leone & -35.44 \\
Cameroon & -49.068 & Lesotho & -44.428 & Somalia & no data \\
Cape Verde & -51.412 & Liberia & -60 & South Africa & -88.693 \\
Central African Republic & -52.012 & Madagascar & -54.297 & South Sudan & no data \\
Chad & -56.459 & Malawi & -56.24 & Sudan & -154.853 \\
Comoros & -349.867 & Mali & -38.901 & Swaziland & -42.155 \\
Congo, Dem. Rep. & -34.908 & Mauritania & -649.334 & Tanzania & -124.502 \\
Congo, Rep. & -45.171 & Mauritius & -29.839 & Togo & -78.739 \\
Cote d'Ivoire & -29.716 & Mayotte & no data & Uganda & -75.925 \\
Equatorial Guinea & -869.616 & Mozambique & -54.583 & Zambia & -31.328 \\
Eritrea & -52.313 & Namibia & -228.327 & Zimbabwe & -33.382 \\
Ethiopia & -363.75 & Niger & -38.408 & & \\
Gabon & -36.566 & Nigeria & no data & & \\
\hline & Threshold Values (for statistical significance) & & \\
& $\mathbf{1 ~ p e r c e n t ~}$ & $\mathbf{5}$ percent & $\mathbf{1 0}$ percent & & \\
\hline & -40.24 & -35.74 & -33.45 & & \\
\hline
\end{tabular}

\subsection{Are These Results Due to Debt Relief?}

As the Clemente, Montañes, and Reyes (1998) test indicated structural breaks in both time series with peaks in expected years and the Elliot and Müller (2006) suggested statistically significant difference in determinants of FDI for particular countries, but not for Africa as a whole, this section incorporates a natural experiment that exploits information captured in panel data. For the natural experiment around an event study, we use:

- Control (non-HIPC countries) vs. HIPC shows whether the effects were due to HIPC or not.

- Control (non-African countries) vs. Africa shows whether the effects were specific to Africa.

- Control (non-indebted countries) vs. "Event" shows whether the effects were due to debt relief (a "proxy-plus").

We develop the econometric approach for an event study by isolating both a policy event (such as the HIPC decision point) and a control group (such as non-HIPC country) (Note 17). The control group is impacted by all other influences except for the policy event. This approach directly accounts for the implications that the "something" that happened in Africa over the past decade resulted from deeper shifts in economic governance; that is, we isolate the "proxy-plus." The control groups address whether HIPC occurred due to better economic governance, leading to a shift in the impacts of FDI, or whether better economic governance lead to both HIPC debt relief and a shift in the inflows of foreign direct investment. Figure 8 diagrams the Event study into quadrants.

Figure 6. Event study

\begin{tabular}{lll}
\hline & Non-HIPC Country $(\mathbf{J}=\mathbf{0})$ & HIPC Country $(\mathbf{J}=\mathbf{1})$ \\
\hline Pre-Decision Point $(\mathrm{D}=\mathbf{0})$ & Event $=0$ & Event $=0$ \\
Post-Decision Point $(\mathrm{D}=\mathbf{1})$ & Event $=0$ & Event $=1$ \\
\hline
\end{tabular}

The estimating equation is based on Anyanwu's (2012) determinants of FDI in Africa:

$$
\begin{gathered}
F D I_{i, t}=\alpha_{i}+\alpha_{t}+\beta_{1} F D I_{i, t-1}+\beta_{2} \text { urbpop }_{i, t}+\beta_{3} \text { GDPpc }_{i, t}+\beta_{4} \text { Trade }_{i, t}+\beta_{5} \text { Credit }_{i, t}+\beta_{6} \text { ExRate }_{i, t}+ \\
\beta_{7} \text { Telephone }_{i, t}+\beta_{8} O D A_{i, t}+\beta_{9} \text { GDPgrowth }_{i, t}+\varepsilon_{i, t}
\end{gathered}
$$

We conduct estimation of (1) for the three natural experiments using the Stata command xtregar to account for autoregressivity in the time series. Table 7 shows the results. 
Table 7. Results of FDI flows

\begin{tabular}{|c|c|c|c|c|c|c|c|}
\hline & Baseline & Control & HIPC & Control & Event & Control & Africa \\
\hline \multirow[t]{2}{*}{ L.FDIflows } & $0.467 * * *$ & -0.0443 & $0.397 * * *$ & $0.403 * * *$ & -17.12 & $0.671^{*}$ & -0.206 \\
\hline & (17.59) & $(-0.63)$ & $(7.42)$ & (14.40) & $(-0.11)$ & $(2.17)$ & $(-0.66)$ \\
\hline \multirow[t]{2}{*}{ urbpop } & $1.481 * * *$ & $1.811^{*}$ & -0.614 & $1.586^{* * *}$ & $0.386^{* * *}$ & 0.242 & 1.292 \\
\hline & $(4.73)$ & (1.97) & $(-1.08)$ & $(4.46)$ & $(4.27)$ & $(0.11)$ & $(0.59)$ \\
\hline \multirow[t]{2}{*}{ GDPpc } & $0.0680 *$ & 0.234 & -0.145 & $0.0757^{*}$ & 0.0356 & -0.0714 & 0.138 \\
\hline & $(2.14)$ & $(0.98)$ & $(-0.63)$ & $(2.32)$ & $(0.11)$ & $(-0.17)$ & $(0.33)$ \\
\hline \multirow[t]{2}{*}{ Trade } & $1.693 *$ & 1.443 & 0.119 & 1.432 & 0.143 & 1.752 & -0.0886 \\
\hline & $(2.21)$ & $(0.59)$ & $(0.08)$ & (1.73) & $(0.86)$ & $(0.68)$ & $(-0.03)$ \\
\hline \multirow[t]{2}{*}{ Credit } & $8.701 * * *$ & $34.50 * * *$ & $-16.02 * * *$ & $10.35^{* * *}$ & 1.810 & 2.781 & 7.284 \\
\hline & $(4.32)$ & $(5.37)$ & $(-4.11)$ & $(4.82)$ & $(1.41)$ & $(0.53)$ & (1.27) \\
\hline \multirow[t]{2}{*}{ ExRate } & 0.0537 & 1.749 & -0.853 & 0.0522 & -10.10 & -1.681 & 1.733 \\
\hline & $(1.53)$ & (1.72) & $(-1.67)$ & $(0.63)$ & $(-1.83)$ & $(-0.57)$ & $(0.58)$ \\
\hline \multirow[t]{2}{*}{ Telephone } & $-24.00 * *$ & $-73.87 * *$ & 34.16 & $-29.17 * *$ & -0.0106 & 14.29 & -40.06 \\
\hline & $(-3.11)$ & $(-3.04)$ & (1.77) & $(-2.98)$ & $(-0.12)$ & $(0.35)$ & $(-0.96)$ \\
\hline \multirow[t]{2}{*}{ ODAflows } & $0.00245^{* * *}$ & $0.0118 * * *$ & $-0.0057 * * *$ & $0.00307 * * *$ & 1.448 & -0.00026 & 0.00298 \\
\hline & (5.09) & (7.48) & $(-6.04)$ & $(5.82)$ & $(0.04)$ & $(-0.13)$ & $(1.41)$ \\
\hline \multirow[t]{2}{*}{ GDPgrowth } & 2.411 & 5.961 & -2.226 & 2.896 & $-0.00171 *$ & 3.141 & -0.479 \\
\hline & $(1.01)$ & $(0.73)$ & $(-0.50)$ & (1.16) & $(-2.07)$ & $(0.30)$ & $(-0.04)$ \\
\hline \multirow[t]{2}{*}{ _cons } & $-774.0 * * *$ & $-500.6 * * *$ & & $-800.2 * * *$ & -5.000 & $-736.6 * * *$ & \\
\hline & $(-6.52)$ & $(-3.54)$ & & $(-6.20)$ & $(-0.68)$ & $(-5.21)$ & \\
\hline $\mathbf{N}$ & 1303 & 1303 & & 1303 & & 1303 & \\
\hline adj. R-sq & 0.303 & 0.358 & & 0.304 & & 0.307 & \\
\hline
\end{tabular}

Notes: t-statistics in parentheses, ${ }^{*} \mathbf{p}<\mathbf{0 . 0 5},{ }^{* *} \mathrm{p}<0.01, * * * \mathrm{p}<0.001$.

None of the coefficients in the analysis for Africa are statistically significant. This lack of statistical relevance is due in part to the small sample size of non-African countries but underscores a stronger implication: the variance of determinants of FDI are not affected as much by the presence of countries in sub-Saharan Africa as much as by the HIPC designation and the "event" of the Decision Point for debt relief. Debt relief is a story about Africa only because most debt relief took place in Africa.

The baseline results are consistent with Anyanwu (2012) with the statistically significant variables UrbPop, Trade, and ODA carrying signs consistent the conclusions that: 1) FDI flows to countries that receive more foreign aid; 2) large market size (represented by Urban Population) attracts FDI; and 3) export-oriented economies facilitate foreign direct investment. Also in the baseline, the coefficient on Telephone is negative, which is counterintuitive and calls into question the continued relevance of using kilometers of telephone lines as a measure of infrastructure in developing countries.

The impact of debt relief initiatives is manifest in the variables Credit and ODA. The coefficient on Credit is positive in the baseline model, which suggests that higher levels of domestic credit to the private sector (as a percentage of GDP) has a positive impact on FDI flows. For the HIPC analysis, the Credit coefficient is positive for the control groups in both the HIPC and Event analyses but statistically half the size for HIPC countries (Note 18). These results suggest that the impact of domestic markets on FDI is a dominant factor in financially secure (non-HIPC) economies. The Event study provides further supporting evidence in that the diminished impact on the Credit coefficient is statistically insignificant. The conclusion is that by the standards of statistical relevance, Credit has a negative influence on FDI for heavily indebted poor countries that disappeared following the debt relief initiatives. That is, prior to the initiatives, a heavy dose of domestic credit negatively impacted FDI. Following debt relief, the levels of domestic credit did not affect FDI. By these standards, recently increasing debt levels in formerly indebted countries are "a good kind of debt."

ODA follows a similar pattern, although with a much smaller impact on the magnitude of the coefficient. While FDI may follow foreign aid, the effect is diminished in heavily indebted, poor countries. These results are consistent for both the HIPC and Event control groups, although the HIPC countries have a smaller aggregate coefficient for ODA flows (Note 19). This result suggests that while FDI may follow foreign aid, the effect is diminished in heavily-indebted, poor countries. The diminished effect on ODA does not extend to the Event analysis, suggesting that following the Decision Point the relationship between foreign aid and foreign direct investment is the same in HIPC countries as elsewhere, which supports the widely-expressed idea that "aid 
works in good environments." (Note 20)

\section{Conclusions}

Our results suggest that the next step in African development, following debt relief, will likely be investment. We conclude that a fundamental change in economic governance occurred over the past decade creating market-based incentives for private investment. Although the climate can shift again quickly, through such events as another global recession or a resurgence of civil conflict, the evidence implies that the debt relief initiatives were successful and African economies are currently in the process of sustained, market-based growth.

While recognizing that HIPC and MDRI may be a proxy for deeper economic governance, debt relief itself appears to have played a substantive role regarding foreign direct investment. Since much of the $\$ 75$ billion in debt relief granted to HIPC countries was in the form of overseas development assistance, these results pose an interesting question about the relationship between foreign aid and FDI, whether aid is a "signal" for confidence in the markets of developing countries or whether aid offers a direct channel to improve market conditions. This paper has demonstrated a direct impact, to the extent that debt relief itself was manifested in assistance and has positively affected the flows of foreign direct investment to formerly indebted countries.

Another conclusion to be drawn is that there is no statistical difference for HIPC countries in Africa compared to HIPC countries outside of Africa. To the extent that African countries have historically offered different incentives for FDI and other market-based activities, these differences appear to have arisen because countries in Africa have skewed towards being heavily-indebted and poor. One story is that when it comes to debt and FDI, Guinea is more like Guyana than like Botswana. Debt relief is a story about Africa only because most debt relief took place in Africa. An implication is that following the debt relief initiatives, we can anticipate that FDI will flow to Africa by similar mechanisms as in other regions. If the continent is "open for business", the ability for countries to again engage in public financing to improve market conditions should be anticipated as a positive turn of events.

One future direction will analyze FDI by sector, specifically disaggregating the flows to account for extractive industries. As foreign investment in Africa has traditionally been focused on natural resources, further indications that the market potential of the region has shifted in the past decade will be indicated by the mix of investment opportunities. This line of research would also benefit from a stronger measure of infrastructure that accounts for roads, electricity, and internet access.

\section{Acknowledgements}

We thank participants at the 2012 Western Economic Association International in S Francisco, CA, the Analytical Skills Session in Monrovia, Liberia, and at the Office of Competition and Economic Analysis, the Overseas Private Investment Corporation, and the U.S. International Trade Commission in Washington, DC. Yonatan Woldu of the USAID Knowledge Services Center provided valuable research assistance. Narek Sahakyan, Sheila Desai, Charles Richter, Olesia Kozlova, Joseph Flynn, and two anonymous referees offered helpful comments.

\section{References}

Addison, T. (2006). Debt relief: The development and poverty impact. Swedish Economic Policy Review, 13, 205-230.

Anyanwu, J. (2012). Why Does Foreign Direct Investment Go Where It Goes?: New Evidence from African Countries. Annals of Economics and Finance, 13(2), 433-470.

Asiedu, E. (2002). On the Determinants of Foreign Direct Investment to Developing Countries: Is Africa Different? World Development, 30(1), 107-119. http://dx.doi.org/10.1016/S0305-750X(01)00100-0

Baum, C. F. (2005). Stata: The language of choice for time-series analysis? Stata Journal, 5(1), 46-63.

Baum, C. F., Barkoulas, S., \& Caglayan, M. (1999). Long memory or structural breaks: can either explain nonstationary real exchange rates under the current float? Journal of International Financial Markets, 9(4), 359-376. http://dx.doi.org/10.1016/S1042-4431(99)00018-9

Buraimo, B., Migali, G., \& Simmons, R. (2012). Corruption does not pay: An analysis of consumer response to Italy's Calciopoli scandal. Lancaster University Management School. Paper presented at 2012 Western Economic Association International in San Francisco, CA.

Burnside, C., \& Dollar, D. (2000). Aid, Policies, and Growth. American Economic Review, 90(4), 847-868. http://dx.doi.org/10.1257/aer.90.4.847

Clements, B., Bhattacharyua, R., \& Nguyen, T. O. (2005). Can Debt Relief Boost Growth in Poor Countries? 
International Monetary Fund, Economic Issues No. 34.

Dorsey, T. (2008). A Capital Story. International Monetary Fund Finance and Development, 45(2).

Easterly, W. (2002). How Did Heavily Indebted Poor Countries Become Heavily Indebted? Reviewing Two Decades of Debt Relief. World Development, 30(10), 1677-1696. http://dx.doi.org/10.1016/S0305-750X(02)00073-6

Hepp, R. (2008). Can Debt Relief Buy Growth? Fordham University Discussion Paper No. 2008-22.

International Monetary Fund. (May 2012). Liberia: Eighth Review Under the Three-Year Arrangement Under the Extended Credit Facility.

Levine, R. (1992). A Sensitivity Analysis of Cross-Country Growth Regressions. American Economic Review, $82(4), 942-63$.

McKinsey Global Institute. (2010). Lions on the move: The progress and potential of African economies. McKinsey \& Company.

Moss, T. (2011). African Development: Making Sense of the Issues and Actors (2nd ed.). Boulder, CO: Lynne Rienner Publishers.

Nicholson, M. (2012). Regional variations in the impact of development aid on foreign direct investment. SSRN Working Paper, No. 2140872.

Radelet, S. (2007). Reviving Economic Growth in Liberia. Center for Global Development Working Paper, Number 133.

Radelet, S. (2010). Emerging Africa: How 17 Countries are Leading the Way. Washington, DC: Center for Global Development.

Reisen, H., \& Ndoye, S. (2008). Prudent versus Imprudent Lending to Africa: From Debt Relief to Emerging Leaders. OECD Development Centre Working Paper, No. 268. http://dx.doi.org/10.1787/242613675043

Reiter, S. L., \& Steensma, H. K. (2010). Human Development and Foreign Direct Investment in Developing Countries: The Influence of FDI Policy and Corruption. World Development, 38(12), 1678-1691. http://dx.doi.org/10.1016/j.worlddev.2010.04.005

Rose, A. K. (2004). Do We Really Know That The WTO Increases Trade? American Economic Review, 94(1), 98-114. http://dx.doi.org/10.1257/000282804322970724

\section{Appendix}

Table A-1. Debt-to-export ratios

\begin{tabular}{lllllllll}
\hline Country & $\mathbf{1 9 7 0}$ & $\mathbf{1 9 8 0}$ & $\mathbf{1 9 8 5}$ & $\mathbf{1 9 9 0}$ & $\mathbf{1 9 9 5}$ & $\mathbf{2 0 0 0}$ & $\mathbf{2 0 0 5}$ & $\mathbf{2 0 1 0}$ \\
\hline Angola & & & & $215 \%$ & & $115 \%$ & $49 \%$ & $38 \%$ \\
Benin & $86 \%$ & $214 \%$ & $365 \%$ & $425 \%$ & $345 \%$ & $405 \%$ & $266 \%$ & $130 \%$ \\
Botswana & $73 \%$ & $24 \%$ & $47 \%$ & $26 \%$ & $29 \%$ & $15 \%$ & $9 \%$ & $35 \%$ \\
Burkina Faso & $84 \%$ & $191 \%$ & $333 \%$ & $245 \%$ & $378 \%$ & $600 \%$ & $368 \%$ & \\
Burundi & $58 \%$ & $205 \%$ & $359 \%$ & $1018 \%$ & $899 \%$ & $2014 \%$ & $1457 \%$ & \\
Cameroon & $48 \%$ & $137 \%$ & $116 \%$ & $292 \%$ & $532 \%$ & $441 \%$ & $214 \%$ & $46 \%$ \\
Cape Verde & & & & $311 \%$ & $228 \%$ & $219 \%$ & $130 \%$ & $133 \%$ \\
Central African Republic & $40 \%$ & $97 \%$ & $193 \%$ & $318 \%$ & $414 \%$ & $454 \%$ & $599 \%$ & \\
Chad & $46 \%$ & $162 \%$ & $176 \%$ & $219 \%$ & $266 \%$ & $465 \%$ & $49 \%$ & $52 \%$ \\
Comoros & & $409 \%$ & $690 \%$ & $527 \%$ & $461 \%$ & $669 \%$ & $509 \%$ & $37 \%$ \\
Congo (Brazzaville) & $125 \%$ & $147 \%$ & $243 \%$ & $326 \%$ & $430 \%$ & $185 \%$ & $120 \%$ \\
Congo (Kinshasa) & $45 \%$ & $201 \%$ & $312 \%$ & $372 \%$ & $824 \%$ & $1213 \%$ & $433 \%$ & $169 \%$ \\
Cote d'Ivoire & $72 \%$ & $210 \%$ & $296 \%$ & $504 \%$ & $411 \%$ & $288 \%$ & $143 \%$ & $123 \%$ \\
Djibouti & & & & $64 \%$ & $140 \%$ & $134 \%$ & $141 \%$ & \\
Eritrea & & & & & $28 \%$ & $313 \%$ & $1070 \%$ & $211 \%$ \\
Ethiopia & & & & $1287 \%$ & $1401 \%$ & $558 \%$ & $334 \%$ \\
Gabon & $65 \%$ & $55 \%$ & $58 \%$ & $145 \%$ & $148 \%$ & $112 \%$ & $69 \%$ & $29 \%$ \\
Gambia & $26 \%$ & $133 \%$ & $248 \%$ & $194 \%$ & $228 \%$ & $239 \%$ & $358 \%$ & $199 \%$ \\
\hline
\end{tabular}




\begin{tabular}{|c|c|c|c|c|c|c|c|c|}
\hline Country & 1970 & 1980 & 1985 & 1990 & 1995 & 2000 & 2005 & 2010 \\
\hline Ghana & $121 \%$ & $372 \%$ & $467 \%$ & $376 \%$ & $347 \%$ & $252 \%$ & $174 \%$ & $88 \%$ \\
\hline Guinea & & & & $299 \%$ & $416 \%$ & $417 \%$ & $292 \%$ & $185 \%$ \\
\hline Guinea-Bissau & $0 \%$ & $978 \%$ & $2275 \%$ & $2865 \%$ & $3021 \%$ & $1384 \%$ & & \\
\hline Kenya & $100 \%$ & $158 \%$ & $269 \%$ & $320 \%$ & $248 \%$ & $224 \%$ & $120 \%$ & $95 \%$ \\
\hline Lesotho & $97 \%$ & $79 \%$ & $430 \%$ & $404 \%$ & $355 \%$ & $263 \%$ & $99 \%$ & $76 \%$ \\
\hline Liberia & $68 \%$ & $112 \%$ & $268 \%$ & & & $2319 \%$ & $1940 \%$ & \\
\hline Madagascar & $228 \%$ & $230 \%$ & $720 \%$ & $721 \%$ & $564 \%$ & $394 \%$ & $246 \%$ & \\
\hline Malawi & $192 \%$ & $270 \%$ & $373 \%$ & $348 \%$ & $527 \%$ & $606 \%$ & $480 \%$ & $60 \%$ \\
\hline Mali & $555 \%$ & $277 \%$ & $661 \%$ & $594 \%$ & $568 \%$ & $456 \%$ & $235 \%$ & \\
\hline Mauritania & $31 \%$ & $322 \%$ & $355 \%$ & $454 \%$ & $292 \%$ & $613 \%$ & $344 \%$ & $110 \%$ \\
\hline Mauritius & & $73 \%$ & $100 \%$ & $54 \%$ & $60 \%$ & $34 \%$ & $21 \%$ & $21 \%$ \\
\hline Mozambique & & & $2214 \%$ & $2285 \%$ & $2114 \%$ & $1029 \%$ & $199 \%$ & $170 \%$ \\
\hline Niger & $45 \%$ & $140 \%$ & $410 \%$ & $472 \%$ & $497 \%$ & $534 \%$ & $394 \%$ & \\
\hline Nigeria & $79 \%$ & $47 \%$ & $408 \%$ & $270 \%$ & $274 \%$ & $126 \%$ & $42 \%$ & $11 \%$ \\
\hline Rwanda & $19 \%$ & $113 \%$ & $196 \%$ & $488 \%$ & $1545 \%$ & $841 \%$ & $512 \%$ & \\
\hline Senegal & $61 \%$ & $176 \%$ & $310 \%$ & $258 \%$ & $260 \%$ & $276 \%$ & $164 \%$ & $115 \%$ \\
\hline Seychelles & & $84 \%$ & $81 \%$ & $80 \%$ & $71 \%$ & $63 \%$ & $94 \%$ & \\
\hline Sierra Leone & $46 \%$ & $187 \%$ & $557 \%$ & $807 \%$ & $752 \%$ & $1035 \%$ & $599 \%$ & $239 \%$ \\
\hline Somalia & $212 \%$ & $329 \%$ & $2955 \%$ & $2641 \%$ & & & & \\
\hline South Africa & & & & & $74 \%$ & $67 \%$ & $46 \%$ & $45 \%$ \\
\hline Sudan & $112 \%$ & $642 \%$ & $1251 \%$ & $2958 \%$ & $2561 \%$ & $845 \%$ & $350 \%$ & $178 \%$ \\
\hline Swaziland & $47 \%$ & $51 \%$ & $114 \%$ & $39 \%$ & $24 \%$ & $23 \%$ & $20 \%$ & $30 \%$ \\
\hline Tanzania & & & & $1199 \%$ & $582 \%$ & $525 \%$ & $284 \%$ & $145 \%$ \\
\hline Togo & $32 \%$ & $193 \%$ & $253 \%$ & $235 \%$ & $347 \%$ & $350 \%$ & $197 \%$ & \\
\hline Uganda & $52 \%$ & $285 \%$ & $256 \%$ & $836 \%$ & $532 \%$ & $530 \%$ & $336 \%$ & $73 \%$ \\
\hline Zambia & $85 \%$ & $202 \%$ & $547 \%$ & $585 \%$ & $555 \%$ & $652 \%$ & $216 \%$ & $52 \%$ \\
\hline Zimbabwe & & $50 \%$ & $193 \%$ & $163 \%$ & $183 \%$ & $149 \%$ & $213 \%$ & $139 \%$ \\
\hline
\end{tabular}

Source: World Bank, World Development Indicators and Author Calculations. Countries with no data are removed from the table.

Table A-2. Data summary statistics

\begin{tabular}{llllll}
\hline Variable & Obs. & Mean & Std. Dev. & Min & Max \\
\hline FDI & $\mathbf{1 7 4 2}$ & $\mathbf{3 . 0 7}$ & $\mathbf{8 . 1 7}$ & $\mathbf{( 8 2 . 8 9 )}$ & $\mathbf{1 4 5 . 2 0}$ \\
UrbPop & $\mathbf{2 0 8 0}$ & $\mathbf{0 . 3 1}$ & $\mathbf{0 . 1 5}$ & $\mathbf{0 . 0 3}$ & $\mathbf{0 . 8 6}$ \\
GDPpc & $\mathbf{1 8 8 5}$ & $\mathbf{8 9 1 . 1 8}$ & $\mathbf{1 , 3 2 2 . 6 3}$ & $\mathbf{5 4 . 5 1}$ & $\mathbf{9 , 2 7 9 . 1 1}$ \\
Trade & $\mathbf{1 8 5 5}$ & $\mathbf{7 2 . 8 3}$ & $\mathbf{4 0 . 3 1}$ & - & $\mathbf{2 8 0 . 3 6}$ \\
Credit & $\mathbf{1 8 0 2}$ & $\mathbf{1 8 . 8 4}$ & $\mathbf{1 7 . 8 4}$ & $\mathbf{0 . 6 8}$ & $\mathbf{1 6 1 . 9 8}$ \\
ExRate & $\mathbf{2 1 2 5}$ & $\mathbf{3 3 9 . 0 5}$ & $\mathbf{1 , 1 2 2 . 4 1}$ & $\mathbf{0 . 0 0}$ & $\mathbf{1 8 , 4 9 8 . 6 0}$ \\
Telephone & 1776 & $\mathbf{1 . 9 6}$ & $\mathbf{4 . 0 7}$ & $\mathbf{0 . 0 1}$ & $\mathbf{3 0 . 3 0}$ \\
ODA & $\mathbf{1 8 2 0}$ & $\mathbf{1 2 . 1 7}$ & $\mathbf{1 3 . 1 2}$ & $\mathbf{( 0 . 2 5 )}$ & $\mathbf{1 8 1 . 0 1}$ \\
GDPgrowth & $\mathbf{1 8 9 0}$ & $\mathbf{3 . 7 2}$ & $\mathbf{7 . 2 8}$ & $\mathbf{( 5 1 . 0 3 )}$ & $\mathbf{1 0 6 . 2 8}$ \\
\hline
\end{tabular}




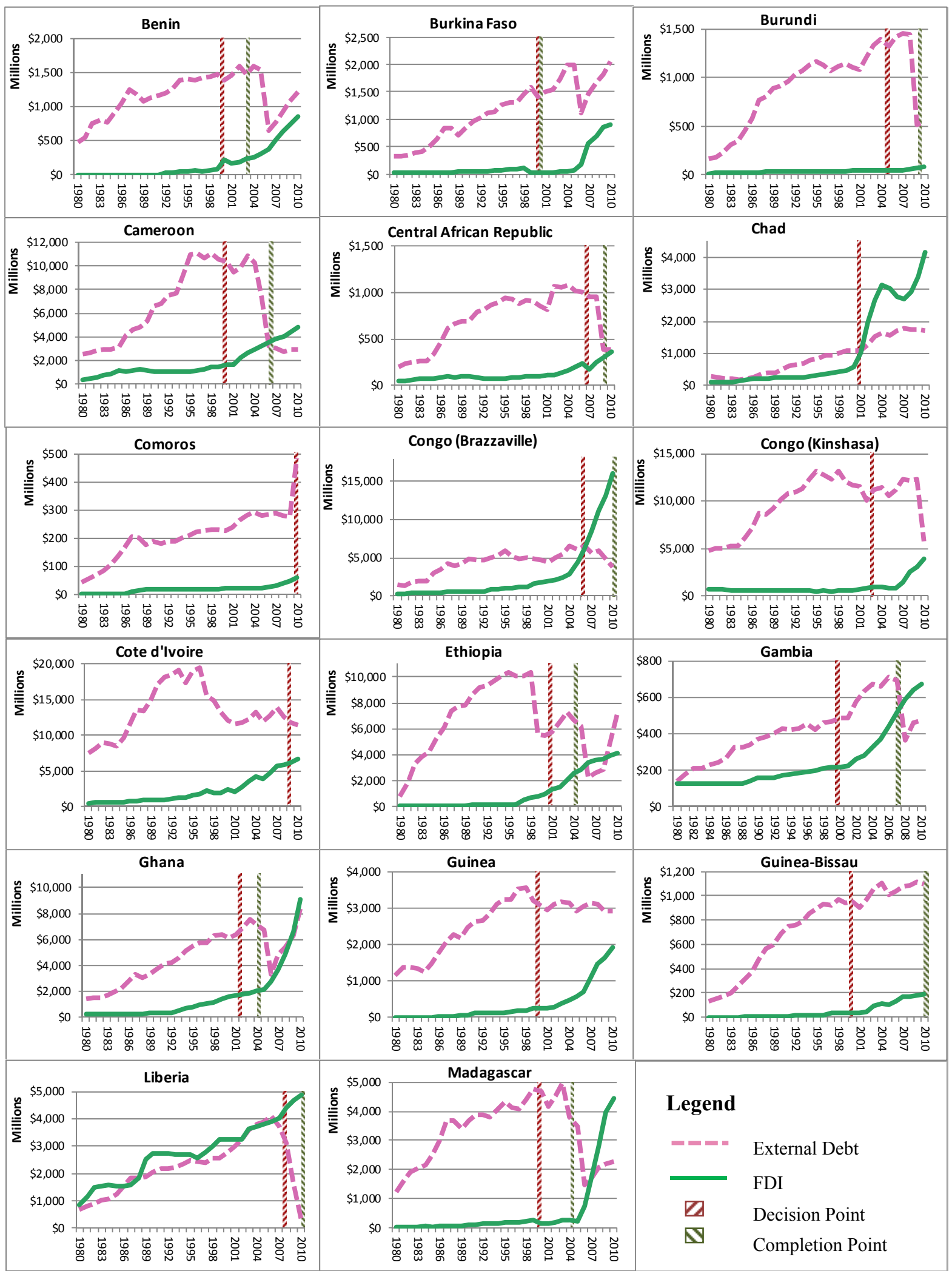




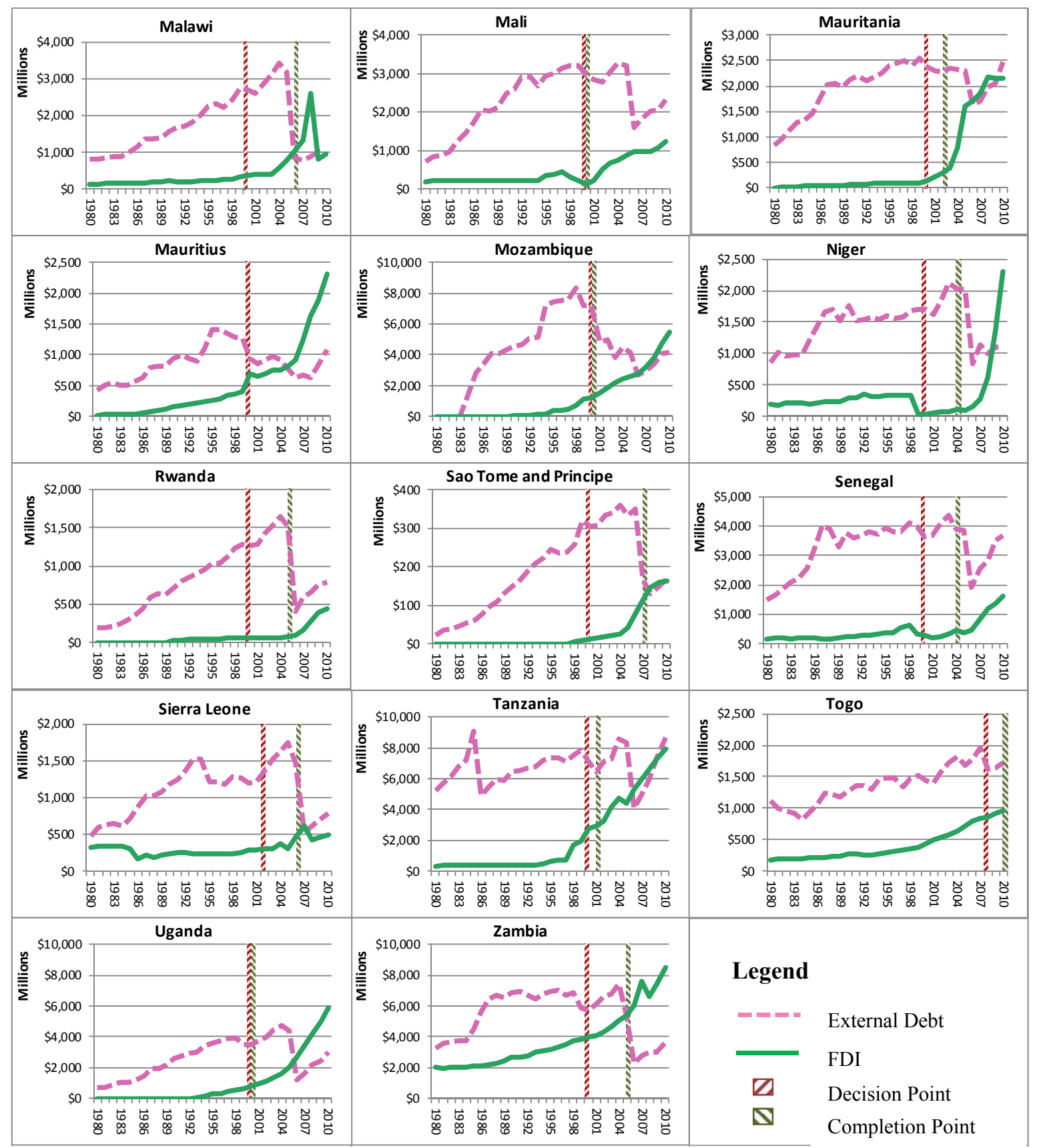

Figure A1. HIPC Countries in Africa 
Table A-3. Structural breaks, debt

\begin{tabular}{llllllll}
\hline Country & One break & \multicolumn{2}{l}{ Two breaks } & Country & One break & \multicolumn{2}{l}{ Two breaks } \\
\hline AGO & 2009 & 2000 & 2004 & MLI & 1986 & 1987 & 2007 \\
BDI & 1988 & 1988 & 2005 & MOZ & 2002 & 1991 & 2002 \\
BEN & 1983 & 1983 & 2007 & MRT & 1983 & 1979 & 1988 \\
BFA & 1988 & 1984 & 1995 & MUS & 1988 & 1988 & 2002 \\
BWA & 2006 & 1988 & 2002 & MWI & 1988 & 1991 & 2007 \\
CAF & 1988 & 1982 & 1988 & NER & 1982 & 1982 & 2007 \\
CIV & 1982 & 1982 & 1993 & NGA & 1984 & 1984 & 2007 \\
CMR & 1996 & 1991 & 2007 & RWA & 1988 & 1989 & 2007 \\
COG & 1982 & 1982 & 1991 & SDN & 1991 & 1983 & 1991 \\
COM & 1988 & 1989 & 2005 & SEN & 1982 & 1983 & 2003 \\
CPV & 2004 & 2000 & 2008 & SLE & 1982 & 1980 & 1988 \\
ERI & 2005 & 2000 & 2005 & STP & 1990 & 1992 & 2004 \\
ETH & 1983 & 1984 & 2000 & SWZ & 1998 & 1979 & 1998 \\
GAB & 1988 & 1988 & 2004 & SYC & 2008 & 2002 & 2007 \\
GHA & 1991 & 1983 & 1992 & TCD & 2005 & 1992 & 2004 \\
GIN & 1989 & 1982 & 1991 & TGO & 1980 & 1980 & 1993 \\
GMB & 1988 & 1983 & 1995 & TZA & 1978 & 1979 & 2003 \\
GNB & 1989 & 1984 & 1991 & UGA & 1988 & 1988 & 2007 \\
KEN & 1988 & 1981 & 1988 & ZAF & 2008 & 2004 & 2007 \\
LBR & 1988 & 1988 & 2004 & ZAR & 1987 & 1979 & 1988 \\
LSO & 1989 & 1984 & 1991 & ZMB & 1982 & 1984 & 2007 \\
MDG & 1982 & 1983 & 2007 & ZWE & 1986 & 1983 & 1991 \\
\hline
\end{tabular}

Table A-4. Structural breaks, FDI

\begin{tabular}{|c|c|c|c|c|c|c|c|}
\hline \multirow{3}{*}{$\begin{array}{l}\text { Country } \\
\text { AGO } \\
\text { BDI }\end{array}$} & \multirow{3}{*}{$\begin{array}{l}\text { One break } \\
\text { gaps in data } \\
1998\end{array}$} & \multirow{2}{*}{\multicolumn{2}{|c|}{$\begin{array}{l}\text { Two breaks } \\
\text { gaps in data }\end{array}$}} & \multirow{3}{*}{$\begin{array}{l}\text { Country } \\
\text { MLI } \\
\text { MOZ }\end{array}$} & \multirow{3}{*}{$\begin{array}{l}\text { One break } \\
2006 \\
\text { gaps in data }\end{array}$} & \multicolumn{2}{|c|}{ Two breaks } \\
\hline & & & & & & 1992 & 2000 \\
\hline & & 1998 & 2007 & & & & \\
\hline BEN & 2004 & 1989 & 2004 & MRT & 2003 & 2000 & 2003 \\
\hline BFA & 2004 & 1991 & 2004 & MUS & 2004 & 1998 & 2006 \\
\hline BWA & 1999 & 1999 & 2003 & MWI & 2000 & 2000 & 2005 \\
\hline $\mathrm{CAF}$ & 2004 & 1979 & 2005 & NER & 2007 & 1978 & 2005 \\
\hline CIV & 1990 & 1990 & 1994 & $\mathrm{NGA}$ & 2004 & 1986 & 2004 \\
\hline CMR & 1999 & 1999 & 2005 & RWA & 2004 & 1991 & 2004 \\
\hline $\mathrm{COG}$ & 2008 & 2004 & 2007 & SDN & gaps in data & & \\
\hline $\mathrm{COM}$ & gaps in data & & & SEN & 2003 & 1994 & 2006 \\
\hline $\mathrm{CPV}$ & 2004 & 1996 & 2005 & SLE & 2001 & 1984 & 2003 \\
\hline ERI & 2000 & 2000 & 2003 & STP & gaps in data & & \\
\hline ETH & gaps in data & & & SWZ & 2003 & 1986 & 2003 \\
\hline GAB & 1999 & 1992 & 1999 & SYC & 2002 & 1994 & 2002 \\
\hline GHA & 2007 & 1995 & 2007 & TCD & 2000 & 2000 & 2004 \\
\hline GIN & 2004 & 1998 & 2004 & TGO & 1998 & 1980 & 1998 \\
\hline GMB & gaps in data & & & TZA & 1996 & 1996 & 2002 \\
\hline GNB & gaps in data & & & UGA & gaps in data & & \\
\hline KEN & 2004 & 1993 & 2004 & ZAF & 1998 & 1994 & 2005 \\
\hline LBR & 2007 & 1987 & 2007 & ZAR & gaps in data & & \\
\hline LSO & 1992 & 1994 & 2001 & ZMB & 2004 & 1986 & 2004 \\
\hline MDG & 2008 & 2004 & 2007 & ZWE & 1996 & 1994 & 1996 \\
\hline
\end{tabular}

\section{Notes}

Note 1. See Easterly (2002) for a description of debt relief efforts in from the 1970s to the new millennium.

Note 2. Unless otherwise indicated, by "Africa" or "the continent" we refer herein to the 49 countries of 
sub-Saharan Africa.

Note 3. Over the last several years many skeptics, like Easterly $(2001,2004)$ and Moyo (2010), have criticized aid in Africa as ineffective.

Note 4. http://www.clubdeparis.org/sections/composition/historique-50-ans

Note 5. Burundi, DRC, Eritrea, Ethiopia, Guinea-Bissau, Liberia, Mozambique, Rwanda, Sierra Leone, Somalia, Sudan, Tanzania, and Uganda all had debt-to-export ratios of more than 1,000 percent for at least 3 years.

Note 6. http://www.imf.org/external/np/exr/facts/hipc.htm

Note 7. The other HIPC countries were Afghanistan, Bolivia, Guyana, Haiti, Honduras and Nicaragua.

Note 8 . This is in end-2009 net present value terms. Source: United Nations, Millennium Development Goals Indicators.

Note 9. International Monetary Fund (2012).

Note 10. http://iresearch.worldbank.org/PovcalNet/index.htm?1

Note 11. This designation contrasts with "FDI-oriented regions" in which investment has overtaken development as the primary source of external capital. FDI-oriented regions include East Asia, Latin America, and the former Soviet Union, where development aid has been drawing down heavily in the past decade and private investment has been increasing substantially.

Note 12. Regarding total global FDI (not just those to developing countries), in 1970, Africa received 6 percent of total global FDI, but these fell to around 1 percent for most of the 1980s and 1990s. Source: UNCTAD Stat. http://unctad.org/en/Pages/Statistics.aspx

Note 13. Note that Asiedu (2002)'s measures infrastructure by the number of telephones per 1,000 people, which may no longer be a reliable indicator given changes in telecommunication technology. She points out that infrastructure might not be as relevant for resource-based FDI, which is common to sub-Saharan Africa.

Note 14. Data according to WDI. These figures dipped slightly following the global recession.

Note 15. Data was not available for Equitorial Guinea, Namibia, Niger, Sao Tome and Principe, and Somalia. Due to the time period under investigation, South Sudan was not included in the analysis.

Note 16. See, among others, Caves (1982) and Markusen (1995).

Note 17. As an example of this approach, see Buraimo, Migali, and Simmons (2012).

Note 18. 34.50-16.02 $=18.48$

Note 19. $0.0118-0.0057=0.0061$

Note 20. See, among others, Burnside and Dollar (2000). 